\title{
INFLUENCE OF PHYSICAL EFFORT ON HABITUAL BODY POSTURES OF SPORTSMEN AND SPORTWOMEN DOING COMPETITIVE SPORTS
}

\author{
WPŁYW WYSIŁKU FIZYCZNEGO NA HABITUALNĄ POSTAWE CIAŁA \\ ZAWODNIKÓW UPRAWIAJĄCYCH SPORT KWALIFIKOWANY
}

\author{
${ }^{1}$ University of Social Sciences, Szczecinek, Poland \\ ${ }^{2}$ Department of the Methodology of Physical Education, University School of Physical Education in Poznań, Poland \\ ${ }^{3}$ Department of Tourism and Recreation, Poznań School of Banking, Poland
}

S u m m a r y

Introduction. Influence of physical training on an individual development is a function of its intensity and consistency. The aim of this research was to present influence of sports training, peculiar to a given sports discipline, on competitors' habitual posture.

Material and method. Measurement of 35 spatial features of habitual body posture, with a use of the photogrammetric method, carried out among 151 competitors representing a variety of sports disciplines: judo, wrestling, volleyball, football, and fencing.

Results. A habitual posture peculiar to each sports discipline was described and importance of differences between features of habitual posture of people not doing qualified sports was established.
Conclusions. (1) Condition of people who do qualified sports may depend on knowledge, skills and responsiveness of a trainer. Diagnostics of body posture may be a crucial criterion in evaluating load applied in asymmetric sports. It enables correction of training methods. It is advisable to provide competitors with versatile training and improve balance between specific groups of muscles, especially in asymmetric disciplines; (2) regular medical examination should become the basis in selecting new entrants in sports clubs; (3) body posture disorders of adult competitors may result from absence of holistic training and inaccuracy in the initial stage of training, incorrect warm-up, and lack of exercises shaping the habit of correct body posture.

\section{Streszczenie}

W stęp. Wpływ ćwiczeń fizycznych na rozwój osobniczy jest funkcją jego intensywności i długotrwałości. Celem podjętych badań jest wykazanie wpływu treningu sportowego właściwego danej dyscyplinie sportowej na habitualną postawę ciała sportowca.

Materiał i metody. Pomiar 35 przestrzennych cech habitualnej postawy ciała dokonano metodą fotogrametryczną wśród 151 zawodników: judo, zapasów, piłki siatkowej, piłki nożnej i szermierki.

Wyniki. Opisano postawę habitualną sportowca właściwą każdej dyscyplinie sportowej, określono istotność różnic z przyjętymi wielkościami cech postawy habitualnej osobników nie uprawiających sportu klasyfikowanego.
Wnioski. (1) Stan zdrowia uprawiających sport kwalifikowany może zależeć od wiedzy, umiejętności i wrażliwości prowadzącego szkolenie sportowe. Istotnym kryterium oceny stosowanych obciążeń w sportach asymetrycznych może być diagnostyka postawy ciała, umożliwiająca korektę metod treningowych i stosowanych środków w jej ramach. Wskazane jest wprowadzenie wszechstronnego szkolenia zawodników i doskonalenia funkcjonalnej równowagi poszczególnych grup mięśniowych, szczególnie w dyscyplinach asymetrycznych; (2) Należy wprowadzić właściwą selekcję w naborze młodych adeptów klubów sportowych w oparciu o systematyczne badania lekarskie; (3) Zaburzenia statyki postawy ciała $\mathrm{w}$ wieku dojrzałego zawodnika mogą być 
konsekwencją nie stosowania zasad treningu holistycznego i błędów w początkowym etapie szkolenia, błędów w

Key words: habitual posture, sport, health

Stowa kluczowe: postawa habitualna, sport, zdrowie

\section{INTRODUCTION}

It has been assumed that increased physical activity is one of key notions in health promotion. Numerous facilities dealing with this issue are included in the Toronto model (HRF - Heath Related Fitness), prepared by Bouchard and Shephard [1], which claims that health stems from components of physical efficiency, which may be further positively modified by regular physical training $[2,3]$. According to this concept, it has been accepted that adaptation involving effort incorporates pro-health elements. The way of creating pro-health adaptation, based on approach towards physical activity as eustress, includes also processes which are hardly beneficial to health. Such detrimental effects of training are mostly noticeable in competitive sports. Apart from effects such as exhaustion (overtraining), a variety of functional and structural changes have been observed. They usually result from specifics of sports discipline. According to Jethon [4], positive influence of physical activity is mainly supported by results of epidemiological research. Comparison between groups of people who exercise against those who do not, showed that in the latter group cases of coronary artery disease, heart failure, atherosclerosis, non-insulin dependent diabetes (type 2 diabetes), osteoporosis, colorectal cancer, and other diseases tend to appear more often. However, these observations may not always be supported by laboratory research, though negative aspects of physical activity are often pointed to. These changes are usually difficult to notice. Nonetheless, in cooperation with other disorders, they may lead to risk of health damage. Exertional female triad is a specific form of health disorder of young women. It consists of fertility disorder (amenorrhoea), eating habits disorder (anorexia, bulimia), and decrease in bone mineral density (osteopenia, osteoporosis). The main reasons for it are changes in life style, especially cutting down on calories intake in order to achieve desired body shape. This results in deficiency in secreting pituitary gland hormones and oestrogens. Reduction of body weight and decline of quality of meals leads to insufficiency of nutrients and, as a consequence, to decrease bone mineral density and immunosuppression $[5,6]$. Photogrammetric examination of body posture of twenty-two boys, pupils from general and sports education classes revealed incorrectness in body rozgrzewce i braku ćwiczeń kształtujących nawyk postawy prawidłowej w jej ramach.

postures of pupils from the general education class, which was also reflected in measurement results: torso forward inclination angle 5.46 degree, lumbar lordosis angle 168.92 degree, thoracic kyphosis angle 157.46 degree, compensation indicator 10.09, depth of thoracic kyphosis $9.01 \mathrm{~mm}$, torso lateral inclination 2.83 degree, pelvic lateral inclination $1.45 \mathrm{~mm}$ and maximal spinal deflection off the straight line C7-S1 $6.27 \mathrm{~mm}$ [7]. Weber [8] believes that physical effort directed at correction of bad posture cannot influence structural changes and bone growth.

The aim of research is to point to influence of sports training specific to a given sports discipline on a sportsperson's habitual body posture.

\section{MATERIAL AND METHODS}

Measurement of selected features of habitual body posture among 151 competitors, aged 11-35 years, was carried out in years 2004-2015. On average the competitors were characterized by 9.5 years of training, body weight $67.29 \mathrm{~kg}$, and height $175.46 \mathrm{~cm}$ (Table I). Competitors of: male judo (Judo M), female wrestling (Zapas. K) and male wrestling (Zapas. M) were members of the national team. While: male volleyball (P.s. M), male football (P.N. M), female fencing (Szerm. K) and male fencing (Szerm. M), were participants of national competitions.

Tabela. I. Charakterystyka materiatu badawczego Table I. Characteristics of research material

\begin{tabular}{|c|c|c|c|c|c|c|}
\hline $\begin{array}{l}\text { Lp. } \\
\text { No. }\end{array}$ & $\begin{array}{l}\text { Dyscyplina } \\
\text { sportowa } \\
\text { Sports } \\
\text { discipline }\end{array}$ & $\begin{array}{l}\text { Liczba } \\
\text { Amount }\end{array}$ & $\begin{array}{l}\text { Staż tr. } \\
\text { (lata) } \\
\text { Training } \\
\text { period } \\
\text { (years) }\end{array}$ & $\begin{array}{l}\text { W. c. } \\
\text { Height }\end{array}$ & $\begin{array}{c}\text { M. c. } \\
\text { Weight }\end{array}$ & $\begin{array}{c}\text { Średni } \\
\text { wiek } \\
\text { Average } \\
\text { age }\end{array}$ \\
\hline 1 & \begin{tabular}{|l|} 
Judo M \\
male judo
\end{tabular} & 27 & 11 & 178.94 & 67.34 & $16-26$ \\
\hline 2 & $\begin{array}{l}\text { Zapasy M } \\
\text { male wrestling }\end{array}$ & 39 & 13 & 179.65 & 79.54 & $18-35$ \\
\hline 3 & \begin{tabular}{|l|} 
Zapasy K \\
female \\
wrestling
\end{tabular} & 29 & 5 & 163.21 & 54.21 & $16-21$ \\
\hline 4 & $\begin{array}{l}\text { P. siatk. M. } \\
\text { male } \\
\text { volleyball }\end{array}$ & 18 & 13 & 186.41 & 79.43 & $20-35$ \\
\hline 5 & \begin{tabular}{|l|} 
P. nożna M \\
male football
\end{tabular} & 15 & 14 & 182.37 & 78.96 & $15-32$ \\
\hline 6 & \begin{tabular}{|l|} 
Szerm. K \\
female fencing
\end{tabular} & 12 & 5 & 165.25 & 53.33 & $11-19$ \\
\hline 7 & \begin{tabular}{|l|} 
Szerm. M \\
male fencing
\end{tabular} & 11 & \multirow[t]{2}{*}{6} & \multirow[t]{2}{*}{172.44} & \multirow[t]{2}{*}{$\begin{array}{l}58.33 \\
\end{array}$} & \multirow[t]{2}{*}{\begin{tabular}{ll|}
$11-19$ \\
\end{tabular}} \\
\hline & $\begin{array}{r}\text { Suma } \\
\text { Total } \\
\end{array}$ & 151 & & & & \\
\hline & $\begin{array}{c}\text { M } \\
\text { Mean }\end{array}$ & & 9.57 & 175.46 & 67.29 & $15.2-26.7$ \\
\hline
\end{tabular}


The measurement involved 35 features, describing body posture in planes: sagittal, coronal, and transverse (Table II). The diagnostics was carried out with use of the moiré method. The measurement stand consisted of: a computer and a card, software, a screen, a printer, and an apparatus for projection and receiving with a camera for measurement of selected spine-pelvis features. It is possible to obtain a spatial image thanks to projecting lines of strictly defined parameters on the back. The lines, while being projected on the back, deform depending on the surface. Thanks to the use of object-lens, the picture may be received by a special optic system with a camera, and subsequently sent to the computer screen. Distortions of lines are saved in the computer and transformed by a numeric algorithm onto a contour map [9]. The picture of the back surface received in this way enables to interpret body posture in a number of ways. Apart from evaluation of torso asymmetry in the coronal plane, there is a possibility to assess spatial values of angular and linear parameters describing pelvis, physiological curvatures and frontal asymmetry of spinous processes, i.e. deflection from the C7-S1 line. A short time of examination helps to avoid fatigue of postural muscles, which happens more often in measurements carried out with use of somatoscopic methods. What is crucial in this method is that all real values of spatial position of different body parts are measured simultaneously [10].

Tabela II. Opis wybranych cech opisujacych postawę ciata Table II. Description of features characterizing body posture

\begin{tabular}{|l|l|l|l|l|}
\hline $\begin{array}{l}\text { Nr } \\
\text { No }\end{array}$ & $\begin{array}{l}\text { Symbol } \\
\text { Symbol }\end{array}$ & \multicolumn{3}{|c|}{$\begin{array}{l}\text { Parametry } \\
\text { Parameters }\end{array}$} \\
\cline { 2 - 5 } & & $\begin{array}{c}\text { Miano } \\
\text { Unit }\end{array}$ & \multicolumn{1}{|c|}{$\begin{array}{c}\text { Nazwa } \\
\text { Name }\end{array}$} & \multicolumn{1}{c|}{$\begin{array}{c}\text { Opis } \\
\text { description }\end{array}$} \\
\hline \multicolumn{2}{|c|}{$\begin{array}{l}\text { Płaszczyzna strzałkowa } \\
\text { Sagittal plane }\end{array}$} \\
\hline 1 & $\begin{array}{l}\text { Alfa } \\
\text { alpha }\end{array}$ & $\begin{array}{l}\text { Stopnie } \\
\text { Degrees }\end{array}$ & $\begin{array}{l}\text { Nachylenie odcinka lędźwiowo-krzyżowego } \\
\text { Inclination of lumbosacral section }\end{array}$ \\
\hline 2 & $\begin{array}{l}\text { Beta } \\
\text { beta }\end{array}$ & $\begin{array}{l}\text { Stopnie } \\
\text { degrees }\end{array}$ & $\begin{array}{l}\text { Nachylenie odcinka piersiowo-lędźwiowego } \\
\text { Inclination of thoracic-lumbar section }\end{array}$ \\
\hline 3 & $\begin{array}{l}\text { Gamma } \\
\text { Gamma }\end{array}$ & $\begin{array}{l}\text { Stopnie } \\
\text { degrees }\end{array}$ & $\begin{array}{l}\text { Nachylenie odcinka piersiowego górnego } \\
\text { Inclination of upper thoracic section }\end{array}$ \\
\hline 4 & $\begin{array}{l}\text { Delta } \\
\text { delta }\end{array}$ & $\begin{array}{l}\text { Stopnie } \\
\text { degrees }\end{array}$ & $\begin{array}{l}\text { Suma wartości } \\
\text { kątów } \\
\text { Sum of angle } \\
\text { values }\end{array}$ & $\begin{array}{l}\text { Delta = Alfa+Beta+Gamma } \\
\text { Delta = Alpha+Beta+Gamma }\end{array}$ \\
\hline 5 & DCK & mm & $\begin{array}{l}\text { Długość } \\
\text { całkowita } \\
\text { kręgosłupa } \\
\text { Length of the } \\
\text { spine }\end{array}$ & $\begin{array}{l}\text { Odległość między punktami C7 i } \\
\text { S1 mierzona w pionie } \\
\text { Distance between points C7 and S1 } \\
\text { measured vertically }\end{array}$ \\
\hline 6 & KPT & $\begin{array}{l}\text { Stopnie } \\
\text { degrees }\end{array}$ & $\begin{array}{l}\text { Kąt wyprostu } \\
\text { tułowia } \\
\text { Angle of torso } \\
\text { extension }\end{array}$ & $\begin{array}{l}\text { Określony jest odchyleniem linii } \\
\text { C7-S1 od pionu (w tył) } \\
\text { Described by deflection of line C7- } \\
\text { S1 from the vertical (backward) }\end{array}$ \\
\hline 7 & KPT - & $\begin{array}{l}\text { Stopnie } \\
\text { degrees }\end{array}$ & $\begin{array}{l}\text { Kąt zgięcia } \\
\text { tułowia } \\
\text { Angle of torso } \\
\text { inclination }\end{array}$ & $\begin{array}{l}\text { Określony jest odchyleniem linii } \\
\text { C7-S1 od pionu (w przód) } \\
\text { Described by deflection of line C7- } \\
\text { S1 from the vertical (forward) }\end{array}$ \\
\hline
\end{tabular}

\begin{tabular}{|c|c|c|c|c|}
\hline 8 & DKP & $\mathrm{mm}$ & \begin{tabular}{|l|} 
Dhugość \\
kifozy \\
piersiowej \\
Length \\
thoracic \\
kyphosis \\
\end{tabular} & $\begin{array}{l}\text { Odległość między punktami LL a } \\
\text { C7 } \\
\text { Distance between points LL and C7 }\end{array}$ \\
\hline 9 & KKP & $\begin{array}{l}\text { Stopnie } \\
\text { degrees }\end{array}$ & \begin{tabular}{|l|} 
Kąt kifozy \\
piersiowej \\
Angle of \\
thoracic \\
kyphosis
\end{tabular} & KKP $=180-($ Beta + Gamma $)$ \\
\hline 10 & RKP & $\mathrm{mm}$ & $\begin{array}{|ll|}\text { Wysokość } & \\
\text { kifozy } & \\
\text { piersiowej } & \\
\text { Height } & \text { of } \\
\text { thoracic } & \\
\text { kyphosis } & \end{array}$ & $\begin{array}{l}\text { Odległość między punktami C7 a } \\
\text { PL } \\
\text { Distance between points C7 and PL }\end{array}$ \\
\hline 11 & GKP & $\mathrm{mm}$ & \begin{tabular}{|l|} 
Głębokość \\
kifozy \\
piersiowej \\
Depth \\
thoracic \\
kyphosis \\
\end{tabular} & $\begin{array}{l}\text { Odległość mierzona poziomo } \\
\text { między liniami pionowymi } \\
\text { przechodzącymi przez punktu PL o } \\
\text { KP } \\
\text { Distance measured horizontally } \\
\text { between vertical lines crossing } \\
\text { points PL and KP }\end{array}$ \\
\hline 12 & DLL & $\mathrm{mm}$ & \begin{tabular}{|l|} 
Długość \\
lordozy \\
lędźwiowej \\
Length of \\
lumbar \\
lordosis
\end{tabular} & $\begin{array}{l}\text { Odległość między punktami S1 a } \\
\text { KP } \\
\text { Distance between points S1 and KP }\end{array}$ \\
\hline 13 & KLL & $\begin{array}{l}\text { Stopnie } \\
\text { Degrees }\end{array}$ & $\begin{array}{l}\text { Kąt lordozy } \\
\text { lędźwiowej } \\
\text { Angle of } \\
\text { lumbag } \\
\text { lordosis }\end{array}$ & KLL $=180-($ Alfa + Beta $)$ \\
\hline 14 & RLL & $\mathrm{Mm}$ & \begin{tabular}{|l|} 
Wysokość \\
lordozy \\
lędźwiow. \\
Height \\
lumbar \\
lordosis \\
\end{tabular} & $\begin{array}{l}\text { Odległość między punktami S1 a } \\
\text { PL } \\
\text { Distance between points S1 and PL }\end{array}$ \\
\hline 15 & GLL - & $\mathrm{mm}$ & \begin{tabular}{|l|} 
Głębokośćc \\
lordozy \\
lędźwiowej \\
Depth of \\
lumbar \\
lordosis
\end{tabular} & $\begin{array}{l}\text { Odległość mierzona poziomo } \\
\text { między liniami pionowymi } \\
\text { przechodzącymi prez punkty PL i } \\
\text { LL } \\
\text { Distance measured horizontally } \\
\text { between vertical lines crossing } \\
\text { points PL and LL }\end{array}$ \\
\hline \multicolumn{5}{|c|}{$\begin{array}{l}\text { Płaszczyzna czołowa } \\
\text { Coronal plane }\end{array}$} \\
\hline 16 & KNT - & $\begin{array}{l}\text { Stopnie } \\
\text { degrees }\end{array}$ & \multirow{2}{*}{$\begin{array}{|lr|}\text { Kąt } & \text { zgięcia } \\
\text { tułowia } & \text { bok } \\
\text { Anglerr } & \text { of } \\
\text { lateral torso } \\
\text { inclination }\end{array}$} & $\begin{array}{l}\text { Określony jest odchyleniem linii } \\
\text { C7-S1 od pionu w lewo. } \\
\text { Described by deflection of the Line } \\
\text { C7-S1 from the vertical to the left }\end{array}$ \\
\hline 17 & KNT & $\begin{array}{l}\text { Stopnie } \\
\text { Degrees }\end{array}$ & & $\begin{array}{l}\text { Określony jest odchyleniem linii } \\
\text { C7-S1 od pionu w prawo } \\
\text { Described by deflection of the Line } \\
\text { C7-S1 from the vertical to the right }\end{array}$ \\
\hline 18 & PBW & $\mathrm{Mm}$ & \begin{tabular}{|l|} 
Prawy bark \\
wyżej \\
Right shoulder \\
higher
\end{tabular} & $\begin{array}{llr}\text { Odległość } & \text { mierzona } & \text { pionowo } \\
\text { między } & \text { liniami } & \text { poziomymi } \\
\text { przechodzącymi przez } & \text { punkty B2 i } \\
\text { B4 } & & \end{array}$ \\
\hline 19 & LBW & $\mathrm{Mm}$ & \begin{tabular}{|l|} 
Lewy brak \\
wyżej \\
Left shoulder \\
higher
\end{tabular} & $\begin{array}{l}\text { Distance measured vertically } \\
\text { between horizontal lines crossing } \\
\text { points B2 and B4 }\end{array}$ \\
\hline 20 & LŁW & $\mathrm{Mm}$ & $\begin{array}{l}\text { Lewa łopatka } \\
\text { wyżej } \\
\text { Left shoulder } \\
\text { blade higher }\end{array}$ & $\begin{array}{lcr}\text { Odległość } & \text { mierzona } & \text { pionowo } \\
\text { między } & \text { liniami } & \text { poziomymi } \\
\text { przechodzącymi przez } & \text { punkty Ł1 } 1 \\
\text { Lp } & & \end{array}$ \\
\hline 21 & PŁW & $\mathrm{Mm}$ & $\begin{array}{l}\text { Prawa lopatka } \\
\text { wyżej } \\
\text { Right shoulder } \\
\text { blade higher }\end{array}$ & $\begin{array}{l}\text { Distance measured vertically } \\
\text { between horizontal lines crossing } \\
\text { points } Ł 1 \text { and } Ł p\end{array}$ \\
\hline 22 & PŁB & $\mathrm{Mm}$ & \begin{tabular}{|l|} 
Kąt dolny \\
lewej lopatki \\
bardziej \\
oddalony \\
Lower angle \\
of r left \\
shoulder blade \\
more distant
\end{tabular} & $\begin{array}{l}\text { Różnica oddalenia dolnych kątów } \\
\text { łopatek od linii wyrostków } \\
\text { kolczystych kręgosłupa mierzona } \\
\text { poziomo na prostych przecho- } \\
\text { dzących przez punkty Łl i Łp } \\
\text { Difference in distances of lower } \\
\text { angles of shoulder blades from the } \\
\text { line of spinous processes, measured }\end{array}$ \\
\hline
\end{tabular}




\begin{tabular}{|c|c|c|c|c|}
\hline 23 & LŁB & $\mathrm{Mm}$ & 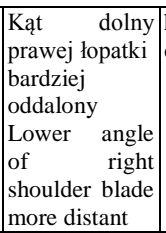 & $\begin{array}{l}\text { horizontally on straight lines } \\
\text { crossing points } \measuredangle 1 \text { and } \measuredangle p\end{array}$ \\
\hline 24 & LTT w & $\mathrm{Mm}$ & $\begin{array}{|lr|}\text { Lewy } & \text { trójkąt } \\
\text { taliowych } & \text { jest } \\
\text { wyższy } & \\
\text { Left } & \text { waist } \\
\text { triangle } & \text { is } \\
\text { higher } & \\
\end{array}$ & \multirow{2}{*}{$\begin{array}{l}\text { Różnica odległości mierzona } \\
\text { pionowo między punktamiT1 i T2 a } \\
\text { T3 i T4. } \\
\text { PLTT = LTT - PTT } \\
\text { Difference in distance measured } \\
\text { horizontally between points T1 - T2 } \\
\text { and T3 - T4 }\end{array}$} \\
\hline 25 & PTT w & $\mathrm{Mm}$ & $\begin{array}{|lr|}\text { Prawy } & \text { trójkąt } \\
\text { taliowych } & \text { jest } \\
\text { wyższy } & \\
\text { Right } & \text { waist } \\
\text { triangle } & \text { is } \\
\text { higher } & \\
\end{array}$ & \\
\hline 26 & LTT s & $\mathrm{Mm}$ & $\begin{array}{|lr|}\text { Lewy } & \text { trójkąt } \\
\text { taliowy } & \text { jest } \\
\text { Szerszy } & \\
\text { Left } & \text { waist } \\
\text { triangle } & \text { is } \\
\text { wider } & \\
\end{array}$ & \multirow{2}{*}{$\begin{array}{l}\text { Różnica odległości } r \\
\text { poziomo mięrerzona } \\
\text { przechodzącymi przez punkty T1 i } \\
\text { T2 a T3 i T4 } \\
\text { Difference in distance measured } \\
\text { horizontally between straight lines } \\
\text { crossing points T1 - T2 and T3 - T4 } \\
\end{array}$} \\
\hline 27 & PTTS s & $\mathrm{Mm}$ & $\begin{array}{|lr|}\text { Prawy } & \text { trójkąt } \\
\text { taliowy } & \text { jest } \\
\text { Szerszy } & \\
\text { Right } & \text { waist } \\
\text { triangle } & \text { is } \\
\text { wider } & \\
\end{array}$ & \\
\hline 28 & KNM & \begin{tabular}{|l|} 
Stopnie \\
Degrees
\end{tabular} & \begin{tabular}{|l|} 
Kąt nachylenia \\
miednicy, \\
prawy talerz \\
biodrowy \\
wyżej \\
Pelvic \\
inclination, \\
right iliac crest \\
is higher \\
\end{tabular} & \multirow{2}{*}{$\begin{array}{l}\text { Kąt między linią poziomą a prostą } \\
\text { przechodzącą przez punkty } \\
\text { M1 a Mp } \\
\text { Angle between horizontal line and a } \\
\text { straight line crossing points M1 and } \\
\text { Mp }\end{array}$} \\
\hline 29 & KNM - & \begin{tabular}{|l|} 
Stopnie \\
Degrees
\end{tabular} & \begin{tabular}{|l|} 
Kąt nachylenia \\
miednicy, \\
lewy talerz \\
biodrowy \\
wyżej \\
Pelvic \\
inclination, \\
left iliac crest \\
is higher \\
\end{tabular} & \\
\hline 30 & UK & $\mathrm{Mm}$ & \begin{tabular}{|l|} 
Maksymalne \\
odchylenie \\
wyrostka \\
kolczystego \\
kręgu w prawo \\
Maximal \\
deflection of \\
spinous \\
process to the \\
right \\
\end{tabular} & \multirow{2}{*}{$\begin{array}{l}\text { Największe odchylenie wyrostka } \\
\text { kolczystego od pionu } \\
\text { wyprowadzonego z S1. Odległość } \\
\text { mierzona jest w osi poziomej. } \\
\text { Maximal deflection of spinous } \\
\text { process from the vertical from S1. } \\
\text { Distance measured in the vertical } \\
\text { axis. }\end{array}$} \\
\hline 31 & UK - & $\mathrm{Mm}$ & \begin{tabular}{|l|} 
Maksymalne \\
odchylenie \\
wyrostka \\
kolczystego \\
kręgu w lewo. \\
Maximal \\
deflection of \\
spinous \\
process to the \\
left \\
\end{tabular} & \\
\hline 32 & $\begin{array}{l}\text { Nr kręgu } \\
\text { Number } \\
\text { of } \\
\text { vertebra }\end{array}$ & & $\begin{array}{l}\mathrm{Nr} \text { kręgu } \\
\text { maksymalnie } \\
\text { odchylonego } \\
\text { w lewo lub } \\
\text { prawo } \\
\text { Number of the } \\
\text { vertebra } \\
\text { maximally } \\
\text { deflected to } \\
\text { the left or to } \\
\text { the right }\end{array}$ & $\begin{array}{l}\text { Numer kręgu najbardziej } \\
\text { odchylonego w lewo lub prawo w } \\
\text { asymetrycznym przebiegu linii } \\
\text { wyrostków kolczystych, licząc jako } \\
1 \text {, pierwszy kręg szyjny (C1) } \\
\text { Jeśli średnia arytmetyczna } \\
\text { przyjmuje wartość np. od } 12,0 \text { do } \\
12,5 \text { to jest to Th5, jeśli od } 12,6 \text { do } \\
12,9 \text { to jest to Th6. } \\
\text { Number of vertebra deflected to the } \\
\text { left or to the right in the asymmetric } \\
\text { line of spinous processes, counting } \\
\text { as the first one, the first cervical } \\
\text { vertebra (C1). If the arithmetic } \\
\text { mean assumes value, e.g. from } 12,0 \\
\text { to } 12,5 \text { it is then Th5, if from } 12,6 \\
\text { to } 12,9 \text { it is then Th6. }\end{array}$ \\
\hline
\end{tabular}

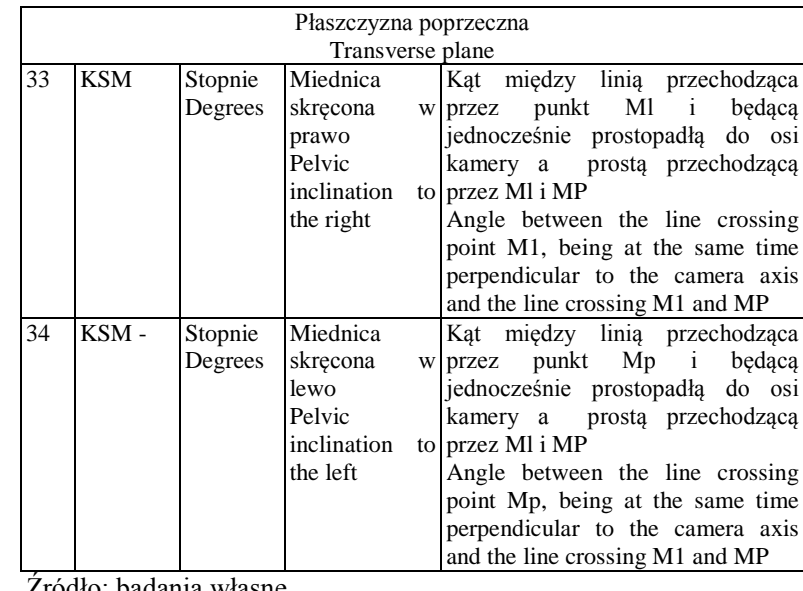

Souce: authors' research

\section{RESULTS}

The diagnostics of the habitual posture features provided 5285 results of measurements. Importance of differences in results between men and women at the age 18 years, doing recreational sports, was analysed [11]. These results were acknowledged as a norm (Table III). Empirical data, in form of qualitative features, underwent statistical analysis. Basic indexes such as arithmetic mean and standard deviation were established. A set of features displayed normal distribution, thus further calculations were based on relevant parametric tests. In order to determine mutual statistical dependency between features, Pearson's correlation coefficients were calculated. The analysis of importance of differences between two means was performed with student's t-test, and homogeneity of variances was checked with $\mathrm{F}$ test; variance ratio test (Table 4, Fig. 1). For the statistical calculations Statistica StatSoft, Inc. (2005). STATISTICA (data analysis software system), version 6.3 www. statsoft. nr lic. AXAP311B316618AR was used.

A habitual posture of a judo competitor in the coronal plane is characterised by a considerably lifted right shoulder and closer location of the left shoulder blade against the line of spinous processes, high asymmetry of the waist triangles, with the left one usually higher, and the right one - wider. There also occurs asymmetric route of the line of spinous processes, with protrusion on the level of the ninth thoracic vertebra. In the transversal plane appears leftsided pelvic torsion of a small angle. In the sagittal plane the posture is properly oriented vertically, lumbar lordosis, lumbosacral and upper thoracic parts are only slightly deepened. The most significant differences against respective postural features of a person doing physical activity on the recreational level 
Tabela III. Średnie wielkości wybranych cech postawy ciała zawodników judo (Judo M), zapaśniczek (Zapasy K) i zapaśników (Zapasy M), piłkarzy nożnych (P.N. M) i siatkówki (P.S. M), szermierek (Szerm. K) i szermierzy (Szerm. M) (n=151)

Table III. Mean values of selected features of bosy posture of judo competitors (Judo M), female wrestlers (Zapasy K), Male wrestlers (Zapasy M), football players (P.N.M), volleyball players (P.S.M), female fencers (Szerm. K) and male fencers (Szerm. M) $(n=151)$

\begin{tabular}{|c|c|c|c|c|c|c|c|c|c|c|}
\hline \multirow[t]{2}{*}{$\begin{array}{l}\text { Lp. } \\
\text { No. }\end{array}$} & \multirow{2}{*}{$\begin{array}{c}\text { Cecha } \\
\text { postawy } \\
\text { ciała } \\
\text { Body } \\
\text { posture } \\
\text { feature } \\
\end{array}$} & \multicolumn{2}{|c|}{$\begin{array}{l}\text { Norma } \\
\text { Norm }\end{array}$} & \multicolumn{7}{|c|}{$\begin{array}{l}\text { Dyscypliny sportowe } \\
\text { Sports disciplines }\end{array}$} \\
\hline & & $\begin{array}{c}\mathrm{M} \\
\text { male }\end{array}$ & $\begin{array}{c}\mathrm{K} \\
\text { female }\end{array}$ & $\begin{array}{c}\text { Judo M } \\
\text { male judo }\end{array}$ & $\begin{array}{c}\text { Zapasy M } \\
\text { male } \\
\text { wrestling }\end{array}$ & $\begin{array}{c}\text { Zapasy K } \\
\text { female } \\
\text { wrestling }\end{array}$ & $\begin{array}{c}\text { P.S. M } \\
\text { male } \\
\text { volleyball }\end{array}$ & $\begin{array}{c}\text { P.N. M } \\
\text { male } \\
\text { football }\end{array}$ & $\begin{array}{c}\text { Szerm. K } \\
\text { female } \\
\text { fencing }\end{array}$ & $\begin{array}{c}\text { Szerm. M } \\
\text { male } \\
\text { fencing }\end{array}$ \\
\hline 1 & KNT & 0.7 & 0.8 & 0.96 & 0.22 & 4.89 & 0 & 0.28 & 0 & 0 \\
\hline 2 & KNT- & 1.2 & 1.3 & 1.56 & 0.47 & 6.67 & 1.02 & 0.49 & 0.25 & 0.27 \\
\hline 3 & KPT & 2.6 & 3.5 & 1.56 & 1.59 & 2.83 & 3.07 & 2.53 & 17.5 & 16.45 \\
\hline 4 & KPT- & 2.5 & 2.0 & 0.96 & 0.58 & 0 & 0.43 & 0.02 & 0 & 0 \\
\hline 5 & KNM & 2.3 & 2.3 & 0.43 & 1.22 & 4.89 & 1.16 & 0.38 & 1.75 & 2.18 \\
\hline 6 & KNM- & 2.4 & 2.1 & 0.37 & 0.12 & 6.67 & 0.17 & 1.32 & 3.33 & 1.18 \\
\hline 7 & KSM- & 4.5 & 5.1 & 2.36 & 4.05 & 3.61 & 5.33 & 4.18 & 1.25 & 0.9 \\
\hline 8 & KSM & 4.3 & 8.4 & 0.49 & 0.12 & 0 & 0.9 & 1.61 & 2.16 & 3 \\
\hline 9 & UK & 2.7 & 4.0 & 0.77 & 1.03 & 2 & 0.98 & 1.14 & 1.16 & 1.63 \\
\hline 10 & UK- & 6.1 & 5.4 & 4.11 & 3.35 & 4.18 & 2.97 & 3.16 & 3 & 3.54 \\
\hline 11 & NK & $\mathrm{Th}_{9}$ & $\mathrm{Th}_{10}$ & $\mathrm{Th}_{9}$ & $\mathrm{Th}_{10}$ & $\mathrm{Th}_{9}$ & $\mathrm{Th}_{3}$ & $\mathrm{Th}_{3}$ & $\mathrm{Th}_{8}$ & $\mathrm{Th}_{7}$ \\
\hline 12 & LŁB & 2.5 & 2.3 & 3.87 & 4.11 & 4.97 & 8.82 & 7.6 & 5.13 & 6.94 \\
\hline 13 & PŁB & 8.5 & 10.3 & 1.52 & 0.5 & 4.31 & 0 & 0 & 1.85 & 0.1 \\
\hline 14 & LŁW & 4.9 & 5.3 & 2.34 & 0.72 & 12.54 & 1.69 & 2.31 & 8.25 & 9.79 \\
\hline 15 & PŁW & 5.9 & 6.2 & 1.72 & 2.92 & 5.12 & 2.15 & 3.25 & 0.99 & 1.86 \\
\hline 16 & LBW & 6.3 & 4.7 & 1.12 & 5.27 & 4.31 & 5.16 & 2.72 & 7.67 & 9.94 \\
\hline 17 & PBW & 7.1 & 6.1 & 4.45 & 2.45 & 4.94 & 1.02 & 1.36 & 2.7 & 0.77 \\
\hline 18 & LTTw & 13.1 & 11.2 & 19.11 & 6.03 & 6.45 & 16.45 & 14.42 & 2.61 & 3.27 \\
\hline 19 & PTTw & 16.0 & 9.3 & 1.63 & 5.11 & 5.45 & 4.9 & 7.84 & 8.04 & 8.36 \\
\hline 20 & LTTs & 9.0 & 9.8 & 3.18 & 1.88 & 2.43 & 1.63 & 3.78 & 4.56 & 4.98 \\
\hline 21 & PTTs & 6.4 & 6.2 & 5.91 & 6.51 & 6.89 & 3.15 & 3.5 & 2.34 & 1.98 \\
\hline 22 & Alfa & 6.5 & 9.3 & 7.02 & 11.5 & 8.53 & 5.97 & 6.22 & 10.33 & 6.36 \\
\hline 23 & Beta & 10.2 & 10.1 & 10.66 & 9.91 & 11.23 & 9.83 & 10.24 & 10.33 & 11 \\
\hline 24 & Gamma & 11.9 & 9.6 & 13.07 & 11 & 9.47 & 10.38 & 11.51 & 8.58 & 10.36 \\
\hline 25 & Delta & 28.4 & 28.9 & 30.74 & 32.76 & 28.63 & 26.2 & 27.99 & 29.58 & 27.45 \\
\hline 26 & KLL & 163.3 & 160.4 & 162.29 & 168.66 & 160.7 & 166.56 & 171.88 & 159 & 162.63 \\
\hline 27 & DLL & 278.6 & 271.9 & 246.16 & 234.98 & 388.13 & 263 & 237.86 & 437.33 & 431.18 \\
\hline 28 & RLL & 156.1 & 154.7 & 135.54 & 126.66 & 226.23 & 142.83 & 119.32 & 263.25 & 256.81 \\
\hline 29 & GLL- & 19.5 & 18.1 & 17.85 & 15.54 & 37.23 & 17.6 & 17.27 & 39.91 & 38.09 \\
\hline 30 & KKP & 158.1 & 160.3 & 156.28 & 158.92 & 159.5 & 159.77 & 158.23 & 160.75 & 158.54 \\
\hline 31 & DKP & 342.8 & 310.7 & 318.38 & 304.51 & 464.83 & 315.78 & 317.24 & 304.66 & 318.63 \\
\hline 32 & RKP & 241.5 & 214.1 & 226.9 & 222.59 & 306.97 & 215.54 & 361.39 & 330 & 243.36 \\
\hline 33 & GKP & 22.4 & 21.0 & 21.11 & 18.7 & 29.22 & 21.03 & 20.38 & 27.16 & 36.27 \\
\hline 34 & DCK & 395.7 & 367.5 & 363.54 & 346.46 & 433.13 & 358.38 & 347.42 & 593.33 & 600 \\
\hline
\end{tabular}

Source: authors' research

Źródło: badania własne

appear in parameters of the coronal plane, excluding torso forward inclination. In the sagittal plane these are mainly features of thoracic kyphosis, length and height of lumbar lordosis, as well as length of the spine. The judo training does not seem to have any influence on left-sided pelvic torsion in the transversal plane, asymmetry in width of waist triangles and partial angles of spinal physiological curvatures (alpha and beta), (Table IV, Fig. 1).

In comparison with similar postures of men on a similar ontogenetic stage and doing sports moderately, the habitual postures of volleyball players in the coronal plane is characterised by: slight left-sided lateral torso inclination, lifted left shoulder, wider and higher left waist triangle and lifted right iliac crest, with the left shoulder blade placed much closer to the spine. Maximal deflection of the spinous process from the straight line, when it occurs, is directed to the right, and on the level of the third thoracic vertebra. If it occurs to the left, then the values are higher. Pelvic torsion in the transversal plane the pelvis occurs more often to the left than to the right. In the sagittal plane, it shows a significant torso extension, average degree of decrease in depth and angle of thoracic kyphosis, significant decrease in depth and angle of lumbar lordosis, and very small lateral inclination of lumbosacral part of the spine. The most important differences in postures between players and people doing sports recreationally appear in the parameters of the coronal plane. In the sagittal plane these are mainly features of thoracic kyphosis, lumbar lordosis and total length of the spine. Exception here is the angle of thoracic kyphosis, which only slightly differs from the same parameter measured for a person who does not do any competitive sport. A complete lack of influence can be observed in pelvic left-sided torsion in the 
Tabela IV. Istotność różnic cech habitualnej postawy ciała między osobnikami uprawiajacymi i nie uprawiającymi sport kwalifikowany

Table IV. Importance of differences in features of habitual postures between people doing sports recreational and competitive

\begin{tabular}{|c|c|c|c|c|c|c|c|c|c|c|c|c|c|c|}
\hline \multirow[t]{3}{*}{$\begin{array}{l}\text { Cecha } \\
\text { Feature }\end{array}$} & \multicolumn{14}{|c|}{$\begin{array}{l}\text { Dyscypliny sportowe } \\
\text { Sports disciplines }\end{array}$} \\
\hline & \multicolumn{2}{|c|}{$\begin{array}{l}\text { Judo M } \\
\text { male judo }\end{array}$} & \multicolumn{2}{|c|}{$\begin{array}{l}\text { Zapasy M } \\
\text { male wrestling }\end{array}$} & \multicolumn{2}{|c|}{$\begin{array}{l}\text { Zapasy K } \\
\text { female wrestling }\end{array}$} & \multicolumn{2}{|c|}{$\begin{array}{l}\text { P.S. M } \\
\text { male volleyball }\end{array}$} & \multicolumn{2}{|c|}{$\begin{array}{l}\text { P.N. M } \\
\text { male football }\end{array}$} & \multicolumn{2}{|c|}{$\begin{array}{l}\text { Szerm. K } \\
\text { female fencing }\end{array}$} & \multicolumn{2}{|c|}{$\begin{array}{l}\text { Szerm M } \\
\text { male fencing }\end{array}$} \\
\hline & P-value & $\mathrm{p}$ & $\mathrm{p}$-value & $\mathrm{p}$ & $\mathrm{p}$-value & $\mathrm{p}$ & $\mathrm{p}$-value & $\mathrm{p}$ & $\mathrm{p}$-value & $p$ & $\mathrm{p}$-value & $p$ & p-value & $p$ \\
\hline KNT & 0,0340 & $*$ & 2,2806 & $* * *$ & 0,0010 & $* *$ & 2,7670 & $* * *$ & 0,0101 & $*$ & 0,0002 & $* * *$ & 0,0101 & $*$ \\
\hline KNT- & 0,0264 & $*$ & 5,4508 & $* * *$ & 0,0344 & $*$ & 0,3628 & & 0,0010 & ** & 0,0002 & **** & 2,7706 & **** \\
\hline KPT & 9,2912 & $* * *$ & 5,1706 & $* * *$ & 3,7511 & $* * *$ & 0,1498 & & 0,8493 & & 1,6230 & $* * *$ & 1,2531 & *** \\
\hline KPT- & 7,2021 & $* * *$ & 7,8216 & $* * *$ & 4,4719 & $* * *$ & 3,5303 & $* * *$ & 1,0210 & $* * *$ & 2,4608 & $* * *$ & 1,6508 & *** \\
\hline KNM & 2,6921 & $* * *$ & 1,5210 & $* * *$ & 3,4555 & $* * *$ & 4,2756 & $* * *$ & 1,5412 & $* * *$ & 0,7113 & & 0,0340 & $*$ \\
\hline KNM- & 7,2114 & *** & 1,4627 & $* * *$ & 3,7185 & **** & 8,6746 & $* * *$ & 0,0013 & $* *$ & 0,0019 & *** & 4,0507 & *** \\
\hline KSM- & 0,1835 & & 0,0657 & & 8,0467 & **** & 0 & $* * *$ & 0,4117 & & 3,8615 & $* * *$ & 9,1418 & *** \\
\hline KSM & 4,2132 & $* * *$ & 7,8280 & $* * *$ & 1,5507 & $* * *$ & 2,3068 & $* * *$ & 2,3248 & $* * *$ & 1,3209 & $* * *$ & 3,7416 & **** \\
\hline UK & 4,7912 & $* * *$ & 4,5431 & $* * *$ & 5,0514 & $* * *$ & 4,4126 & $* * *$ & 1,6711 & $* * *$ & 7,5405 & $* * *$ & 1,2711 & *** \\
\hline UK- & 2,1721 & $* * *$ & 1,8620 & **** & 6,9312 & $* * *$ & 5,9909 & **** & 7,0910 & **** & 4,2706 & **** & 7,1607 & **** \\
\hline NK & 0,1231 & & 0,3141 & & 0,3216 & & 0,1272 & & 0,1789 & & 0,3167 & & 0,1765 & \\
\hline LŁB & 2,6621 & $* * *$ & 1,5733 & $* * *$ & 2,8123 & $* * *$ & 0,5485 & & 7,3611 & $* * *$ & 0,0226 & $*$ & 7,2812 & **** \\
\hline PŁB & 0,0006 & $* * *$ & 4,6517 & $* * *$ & 3,1223 & $* * *$ & 9,2711 & $* * *$ & 0,1235 & & 8,4808 & $* * *$ & 0,2187 & \\
\hline LŁW & 2,2312 & $* * *$ & 3,5654 & $* * *$ & 2,1894 & $* * *$ & 4,7898 & $* * *$ & 2,1709 & *** & 4,8922 & $* * *$ & 8,0508 & **** \\
\hline PŁW & 1,2521 & **** & 4,0725 & $* * *$ & 0,0049 & ** & 7,8072 & $* * *$ & 1,0308 & *** & 7,9614 & **** & 9,1418 & *** \\
\hline LBW & 3,7521 & $* * *$ & 0,0007 & $* * *$ & 0,1802 & & 0,0110 & $*$ & 3,0913 & $* * *$ & 2,2310 & $* * *$ & 8,9811 & *** \\
\hline PBW & 1,9213 & $* * *$ & 1,6949 & $* * *$ & 0,0011 & *** & 1,4191 & $* * *$ & 6,3430 & *** & 7,1271 & $* * *$ & 1,7091 & *** \\
\hline LTTw & 1,1823 & $* * *$ & 1,6245 & **** & 1,8641 & **** & 4,9343 & $* * *$ & 0,1010 & & 0,1211 & & 0,1235 & \\
\hline PTTw & 1,4481 & **** & 1,7981 & **** & 2,1777 & **** & 2,2556 & $* * *$ & 3,8119 & **** & 3,8617 & $* * *$ & 2,4816 & *** \\
\hline LTTs & 2,4623 & & 5,0980 & $* * *$ & 4,3773 & $* * *$ & 6,8473 & $* * *$ & 4,1818 & $* * *$ & 2,2813 & $* * *$ & 1,6215 & *** \\
\hline PTTs & 0,1443 & & 0,6965 & & 0,7565 & & 2,0618 & $* * *$ & 1,0210 & *** & 2,3810 & $* * *$ & 5,5101 & *** \\
\hline $\begin{array}{l}\text { Alfa } \\
\text { Alpha }\end{array}$ & 0,1389 & & 1,9264 & $* * *$ & 0,0384 & $*$ & 0,2187 & & 0,5552 & & 0,2112 & & 0,0801 & \\
\hline Beta & 0,1902 & & 0,3221 & & 7,2305 & $* * *$ & 0,3898 & & 0,9362 & & 0,1470 & & 0,2150 & \\
\hline Gamma & 0,0009 & **** & 0,0021 & *** & 0,6170 & & 0,0004 & $* * *$ & 0,4122 & & 0,0051 & $* *$ & 0,0127 & $*$ \\
\hline Delta & 5,5312 & $* * *$ & 1,3127 & $* * *$ & 0,5287 & & 0,0001 & $* * *$ & 0,5115 & & 0,1936 & & 0,3125 & \\
\hline KLL & 0,0173 & * & 1,0949 & $* * *$ & 0,4777 & & 1,8475 & $* * *$ & 6,4153 & $* * *$ & 0,3030 & & 0,0315 & $*$ \\
\hline DLL & 6,1982 & $* * *$ & 0 & $* * *$ & 0 & $* * *$ & 2,2720 & $* * *$ & 2,9176 & $* * *$ & 0 & **** & 0 & *** \\
\hline RLL & 1,1113 & $* * *$ & 0 & $* * *$ & 0 & **** & 1,4053 & $* * *$ & 2,1981 & **** & 0 & **** & 0 & *** \\
\hline GLL- & 0,0030 & $* *$ & 1,4117 & $* * *$ & 0 & $* * *$ & 0,0052 & $* *$ & 0,0027 & $* *$ & 3,7991 & $* * *$ & 5,5184 & *** \\
\hline KKP & 2,9112 & $* * *$ & 0,0307 & $*$ & 0,0232 & $*$ & 0,0020 & $* *$ & 0,8258 & & 0,5221 & & 0,4065 & \\
\hline DKP & 4,8101 & $* * *$ & 0 & $* * *$ & 0 & $* * *$ & 7,7650 & $* * *$ & 1,9763 & *** & 0 & *** & 0 & **** \\
\hline RKP & 2,4745 & $* * *$ & 4,1051 & $* * *$ & 0 & $* * *$ & 3,6762 & $* * *$ & 0 & $* * *$ & 0 & *** & 0 & *** \\
\hline GKP & 0,0220 & $*$ & 3,3315 & $* * *$ & 3,969 & *** & 0,0477 & $*$ & 0,0075 & $* *$ & 2,9755 & $* * *$ & 4,6517 & *** \\
\hline DCK & 7,9155 & $* * *$ & 0 & $* * *$ & 0 & $* * *$ & 1,4297 & $* * *$ & 0 & $* * *$ & 0 & $* * *$ & 0 & *** \\
\hline
\end{tabular}

Źródło: badania własne

transverse plane, asymmetric width of waist triangles in the coronal plane, and beta angle in the sagittal one (Table IV, Fig. 1).

A habitual posture of wrestling males in the coronal plane can be identified by: considerably lifted left shoulder and, slightly - right shoulder blade, closer location of the left shoulder blade to the line of spinous processes, substantial asymmetry in width of waist triangles, with the right one usually wider. Also a leftsided protrusion in the line of spinous processes, with a peak on the level of the tenth thoracic vertebra can be observed. In the transversal plane pelvic torsion is usually to the left, of an average angular size. In the sagittal plane, when compared with postures of judo competitors and volleyball players, wrestlers display increased angle of lumbar lordosis and smaller lateral inclination of lumbosacral part, smaller angle and length of thoracic kyphosis, length of the spine in the
C7-S1 part, as well as length and depth of lumbar lordosis.

In the habitual posture of female wrestlers, in comparison with girls who do not do qualified sports, in the coronal plane appears a considerable symmetry of pelvis, shoulders and shoulder blades, which probably results in the left-sided scoliosis on the level of the ninth vertebra. In the transversal plane an increased pelvic torsion, usually left-sided, occurs. In the sagittal plane, the spine is much longer in the section C7-S1, decreased depth of thoracic kyphosis and lumbar lordosis. The most significant difference from the respective postural features of a person doing sport for recreational purpose develop in parameters of the coronal plane, excluding torso inclination. In the sagittal plane these are mainly features of thoracic kyphosis and lumbar lordosis, as well as the length of the spine. In comparison with male wrestlers, women showed weaker influence of training on partial angles 


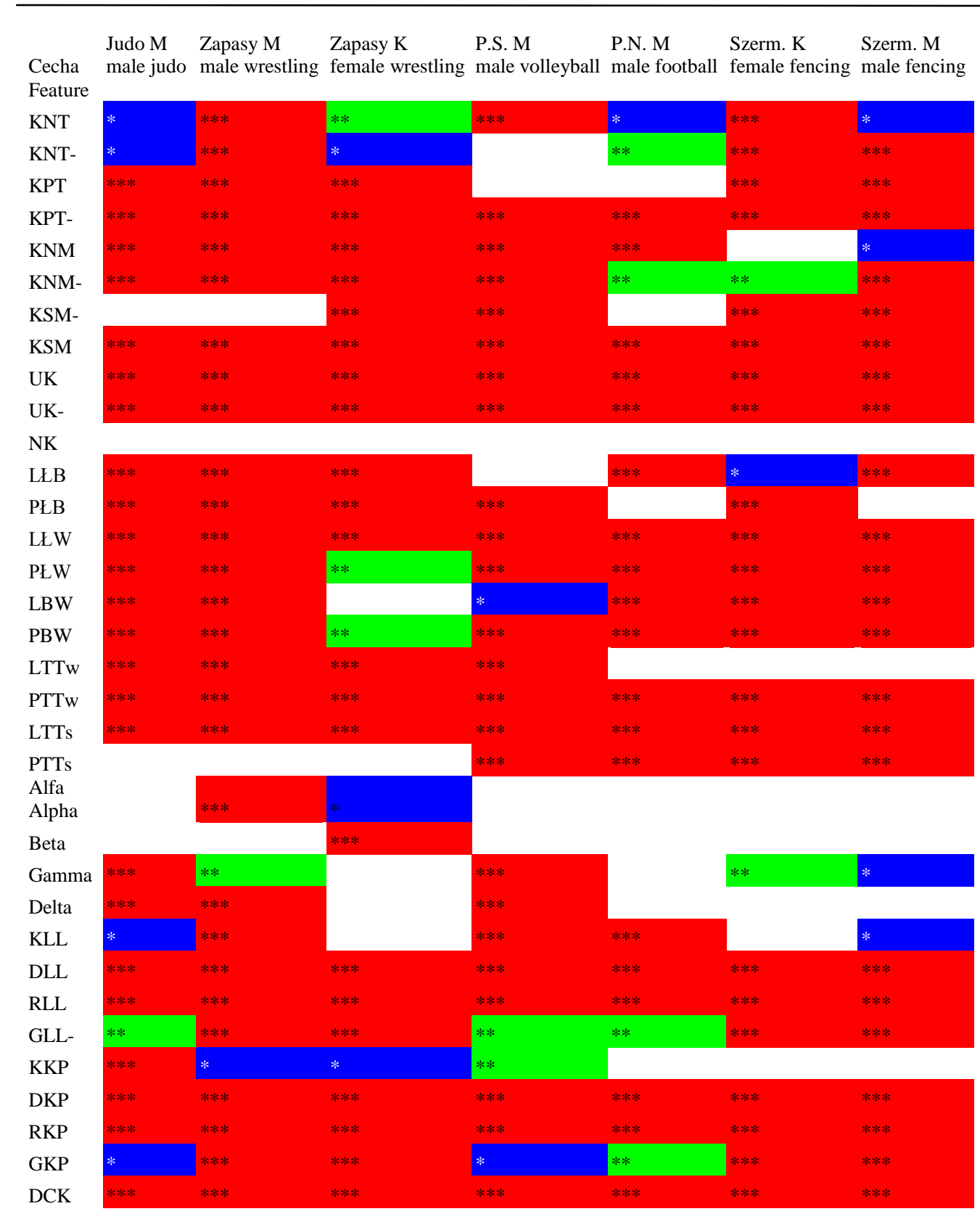

Source: authors' research Źródło: badania własne

Symbols

Difference of high importance (red, $* * *)$

Difference of medium importance (green, $* *$ )

Difference of little importance (blue, *)

Difference of no importance (white)

Objaśnienia

Różnica wysoce istotna (kolor czerwony, ***)

Różnica średnio istotna (kolor zielony, **)

Różnica mało istotna (kolor niebieski, *)

Różnica nieistotna (kolor biały)

Fig. 1. Graphic representation of importance of differences of habitual posture features between people doing sports recreational and competitive

Ryc. 1. Graficzna ilustracja istotności różnic cech habitualnej postawy ciała między osobnikami uprawiajacymi i nie uprawiajacymi sport kwalifikowany

The habitual posture of a football player in the coronal plane is characterised by: moderately lifted shoulder, iliac crest, and the right shoulder blade, closer position of the left shoulder blade to the line of spinous processes, sizeable asymmetry in height of waist triangles, with the left one usually higher than the right one. Also a left-sided protrusion in the line of spinous processes can be observed, most often to the left, on the level of third thoracic vertebra. In the transverse plane appears pelvic torsion to the left, of a small angle. In comparison with a volleyball player's posture in the sagittal plane, a football player displays much smaller angle of lumbar lordosis and torso extension. The most significant differences between a of physiological curvatures (alpha, gamma, delta) and football player and a person doing sports on the angle of lumbar lordosis (Table IV, Fig. 1). recreational level are displayed in parameters of the 
coronal plane, excluding torso extension. In the sagittal plane these are mainly features of thoracic kyphosis and lumbar lordosis, as well as the length of the spine. Partial angles of physiological curvatures (alpha, beta, gamma and delta) remain unchanged by the training, as well as the angle of thoracic kyphosis, and left-sided pelvic torsion in the transversal plane. This influence is similar among the volleyball players. Their training does not seem to influence torso extension and lateral inclination to the left, location of the left shoulder blade against the line of spinous process, and angles of physiological curvatures alpha and beta (Table IV, Fig. 1).

Occurrence of values exceeding norms in description of female and male fencers against people doing sports recreationally is more often within linear parameters of lumbar lordosis and thoracic kyphosis, as well as vertical parameters of torso. On the other hand, there is similarity as far as the angle of both sagittal curvatures of the spine, in the coronal plane: asymmetry of the line of spinous processes and location of lower angles of shoulder blades against it, in the transversal plane: pelvic symmetry. Level and degree of the maximal deflection of the spinous process from the line $\mathrm{C} 7-\mathrm{S} 1$ is similar for both sexes. The most significant differences between females fencers and a person doing sports for recreational purpose are shown in the coronal plane, apart from the value of left-sided pelvic torsion and asymmetry in width of waist triangles. In the sagittal plane these are mainly features of thoracic kyphosis and lumbar lordosis, as well as the length of the spine. No influence of training, or a very limited one, on partial angles of physiological curvatures (alpha, beta and delta), angle of thoracic kyphosis and lumbar lordosis, was observed. Similar results of influence of physical effort within training are displayed by male fencers, which was to be expected. No influence on position of the right shoulder blade against the line of spinous processes, asymmetry of waist triangles, partial angles of physiological curvatures (alpha, beta, delta), and angle of thoracic kyphosis were observed (Table IV, Fig. 1).

What draws one's attention is a very long section of spine C7-S1 features of thoracic kyphosis and lumbar lordosis, quite disproportionate in comparison with other sportsmen and sportswomen. This probably results from the sports discipline trained. Such changes are not displayed by volleyball players, as it could be expected.

\section{DISCUSSION}

The issue of influence of competitive sports on sportsmen's posture was analysed by: Mrozkowiak [11-15], Mrozkowiak, Sokołowski, Kaiser [16-17], Bajorek et al. [18], Barczyk-Pawelec et al. [19], Furgiel et al. [20], Grabara [21-23]. Research of DrzałGrabiec et al. [24] on a group of 50 children aged 7-10 years who had been training karate for two years showed in photogrammetric measurement of selected postural features increased thoracic kyphosis and lumbar lordosis. Research of Grabiec [25] on a group of 125 handball players aged 12-15 years revealed decreased values of partial angles (alpha, beta, gamma), and angle of lumbar lordosis against the control group. Measurement also pointed to correct position of pelvis in the coronal plane, as well as pelvis and shoulder blades in the sagittal plane. Research of Pietraszewska et al. [26] on a group of football players revealed that 29.3 per cent of them had vestigial leftsided scoliosis, as measured by Cobb's angle. Grabara's research [27] on the role of yoga in human's physical activity suggest propagating this system of exercises in all age groups, regardless of fitness level, for people doing recreational sports, as well as an addition to competitive sports. Thanks to its positive influence on spine ailments and attentiveness to correct body posture, some elements of yoga may also be an excellent complement of kinetic therapy, physical education, and physiotherapy exercises. Other research [28] on the group of 54 pupils of sports education class, athletics specialization, displayed asymmetry in the coronal plane (vestigial scoliosis, torso inclination, asymmetry of waist triangles). At the same time the author observes that shape of the spine in the sagittal plane was more often correct among athletes than the control group. Another spatial analysis of body posture with use of projection moiré in a group of 13-yearold handball players showed smaller inclination of thoracic section and bigger torso forward inclination, while in a group of 15-year-olds smaller inclination of lower part of the back, sum of partial angles (delta) and angle of lumbar lordosis, against the group of children not doing competitive sports, was observed. The author concludes: handball training may influence the quality of body posture [29]. Garbara's research [22] concerning influence of training of rhythmic gymnastics point out that when practiced at young age it may influence symmetry of body posture, shape of physiological curvatures of the spine, in particular 
lumbar lordosis. It should be assumed that supplementary exercises, improving one's effort ability, health condition, action of specific systems, organs and the organism as a whole, are essential in forming body posture of diagnosed sportsmen [30]. Continuous increase of level and intensity of training imposes not only the need of detailed medical examination during recruitment, and regular medical control in order to secure optimal health condition of a competitor, but also evaluation of influence of discipline-oriented physical load on his/her organism.

\section{CONCLUSIONS}

In the light of examination results and analysis of the subject literature, the following conclusions may be presented:

1. Condition of people who do qualified sports may depend on knowledge, skills and responsiveness of a trainer. Diagnostics of body posture may be a crucial criterion in evaluating load applied in asymmetric sports, as it enables correction of training methods. It is advisable to provide competitors with versatile training and improve balance between specific groups of muscles, especially in asymmetric disciplines.

2. Regular medical examination should become the basis in selecting new entrants in sports clubs.

3. Body posture disorders of adult competitors may result from absence of holistic training and inaccuracy in the initial stage of training, incorrect warm-up, and lack of exercises shaping the habit of correct body posture.

\section{REFERENCES}

1. Bouchard C, Shephard RJ. Physical activity, fitness, and health: the model and key concepts. [in:] Physical activity, fitness, and health. Bouchard C, Shephard RJ (ed). Human Kinetics, Champaign 1994: 77-88.

2. Dugan SA. Exercise for health and wellness at midlife and beyond: balancing benefits and risks. Phys Med Rehabil Clin N Am 2007, 18: 555-575.

3. Ganley KJ, Paterno MV, Miles C, et al. Health-related fitness in children and adolescents. Pediatr Phys Ther 2012, 23: 208-220.

4. Jethon Z. Aktywność ruchowa jako dystres, Physical activity as a distress, Hygeia Public Health 2013, 48(2): 156-161.

5. Fenichel RM, Warren MP. Anorexia, bulimia, and the athletic triad: evaluation and management. Curr Osteoporos Rep, 2007, 5: 160-164.
6. Warren MP, Chua AT. Exercise-induced amenorrhea and bone health in the adolescent athlete. Ann NY Acad Sci 2008, 1135: 244-252.

7. Kotwicki T. Szulc A. Dobosiewicz K. Patomechanika skolioz idiopatycznych $\mathrm{w}$ ujęciu trójpłaszczyznowym i jej konsekwencje dla doboru ćwiczeń korekcyjnych u dzieci ze skoliozą, Postępy Rehabilitacji, 2001, 15, 3: 4748.

8. Weber M. Entwicklung und Effektivitat der krankengymnastischen Behandlung der Skoliose. Krankengymnastik 1985, 37, 11: 743-748.

9. Świerc A. Komputerowa diagnostyka postawy ciała instrukcja obsługi, Czernica Wrocławska, 2006: 21-28.

10. Mrozkowiak M. Uwarunkowania wybranych parametrów postawy ciała oraz ich zmienność w świetle mory projekcyjnej, Oficyna Wydawnicza Uniwersytetu Zielonogórskiego, 2010:. 242-243.

11. Mrozkowiak M. Modulacja, wpływ i związki wybranych parametrów postawy ciała dzieci i młodzieży w wieku od 4 do 18 lat w świetle mory projekcyjnej, Wydawnictwo Uniwersytetu Kazimierza Wielkiego, Bydgoszcz 2015, tom I, II.

12. Mrozkowiak M. Cechy postawy habitualnej zawodnika judo w płaszczyźnie czołowej i poprzecznej. Annales Universitatis Mariae Curie-Skłodowska, Sectio D: Medicina, Lublin, 2004, Vol. 59. Suppl. 14, N 4: 129132.

13. Mrozkowiak M. Cechy postawy habitualnej zawodnika piłki siatkowej w płaszczyźnie czołowej i poprzecznej. Annales Universitatis Mariae Curie-Skłodowska, Sectio D: Medicina, Lublin, 2004, Vol. 59. Suppl. 14, N 4: 133136.

14. Mrozkowiak M. Cechy postawy habitualnej zawodnika piłki nożnej w płaszczyźnie strzałkowej. Annales Universitatis Mariae Curie-Skłodowska, Sectio D: Medicina, Lublin, 2004, Vol. 59. Suppl. 14, N 4: 126-128.

15. Mrozkowiak M. Cechy postawy habitualnej zawodnika piłki nożnej w płaszczyźnie czołowej i poprzecznej. [W:] Rozwój fizyczny i sprawność ruchowa polskich dzieci i młodzieży. Deckert A, Samborski W. [CD-ROM]. Poznań, Uniwersytet Medyczny im. Karola Marcinkowskiego, 2009: 223-227.

16. 16.. Mrozkowiak M., Sokołowski M., Kaiser A. Characteristics of habitual posture in female wrestlers from the Polish National Team. Medicina dello Sport 2012, Vol. 65, n. 2: 235-251.

17. Mrozkowiak M., Kaiser A., Sokołowski M. Habitual posture of fencers representing the Wielkopolska region, Archives of Budo Science of Martial Arts and Extreme Sport, 2015, v.11: 11-21.

18. Bajorek W., Czarny P., Król M., Rzepko G., Sobo A.,Litwiniuk A. Assessment of postural stability in traditional karate contestants. Journal of Combat Sports and Martial Arts 2011, 1(2); 2: 23-29.

19. Barczyk-Pawelec K., Bańkosz Z., Derlich M. Body postures and asymmetries in frontal and transverse planes in the trunk area in table tennis players. Biol.Sport 2012, 29: 129-134. 
20. Fugiel J., Sławińska T. Postawa ciała dzieci wczesnej specjalizacji sportowej. Antropomotoryka 2012, 21(53): 79.

21. Grabara M. A comparison of the posture between young female handball players and non-training peers. J. Back Musculoskelet. Rehabil 2014 27: 85-92.

22. Grabara M. Postural variables in girls practicing sport gymnastic. Biomed. Hum. Kinetics 2010, 2: 74-77.

23. Grabara M., Hadzik A. The Body posture in young athletes compared to their peers. Polish J. Sports Med. 2009, 25(2): 115-124.

24. Drzał-Grabiec J., Tryszczyńska A. Evaluation of selected postural parameters in children who practice kyokushin karate, Biomedical Human Kinetics 2014, 6, 69-4, DOI: 10.2478/bhk-2014-0013.

25. Grabiec M., A comparison of the posture between young female handball players and non-training peers, Journal of Back and Musculoskeletal Rehabilitation 2014, 27(1):85-92.

26. Pietraszewska J., Pietraszewski B, Burdukiewicz A. Computer evaluation of the body posture of the young soccer players selected biomechanical parameters, Acta Bio-Optica et Informatica Medica 2009, 4, vol. 15.
27. Grabara M. Joga jako odpowiednia dla każdego forma ćwiczeń ruchowych, Turystyka i Rekreacja 2009; 5: 92-98.

28. Grabara M., Hadzik A. Postawa ciała młodych lekkoatletów na tle rówieśników, Medycyna Sportowa 2009, 2 (6), V. 25: 115-124.

29. Grabara M. A comparison of the posture between young female handball players and non-training peers, Journal of Back and Musculoskeletal Rehabilitation 2014: 85-92.

30. Mrozkowiak M. Trening uzupełniający i odnowa biologiczna jeźdźca, Lubuska Agencja Wydawnicza Elblask, 2016: 34-76.

Address for correspondence:

Mirosław Mrozkowiak

Społeczna Akademia Nauk

ul. Kościuszki 47

Szczecinek

Polska

tel. +48602529652

e-mail: magmar54@interia.pl

Received: 20.07.2016

Accepted for publication: 12.08.2016 